\title{
Consumer cooperation as a tool for sustainable rural development
}

\author{
Vladimir Egorov ${ }^{1}$, Sofya Egorova $^{1}$, Andrey Inshakov ${ }^{1, *}$, and Alexander Markarov ${ }^{2}$ \\ ${ }^{1}$ Plekhanov Russian University of Economics, 117997 Moscow, Russian Federation \\ ${ }^{2}$ Yerevan State University, 375025 Yerevan, Armenia
}

\begin{abstract}
The article is devoted to the most popular segment of the global cooperative sector - consumer cooperation. Based on the definition of specific features of this type of cooperation, a special dynamism and adaptability of consumer associations in solving vital social problems and implementing the UN sustainable development goals is shown. The author asserts that the significant growth rates of the world consumer cooperation are determined by the lack of conditionality of its development by the formation of material prerequisites and to a greater extent depend on the organization of information and propaganda work to promote cooperative "self-help". Analysis of world experience has shown that an important factor in the growth of the cooperative movement is the exchange of practices between cooperative organizations on the planet. Being a public organization by nature, consumer cooperation is an essential part of civil society. The analysis and dissemination of international experience in consumer cooperation play a significant role in the activation of civil initiative in self-organization.
\end{abstract}

\section{Introduction}

At each stage of the historical path of countries and peoples, along with current problems, the strategic direction is updated, subordinating all spheres and branches of public life. In fact, the implementation of such a strategy determines the qualitative shifts and boundaries of periods of progressive movement along the path of progress.

A clear definition and correct positioning of political efforts in the vector of the fundamental mainstream requires special foresight and scientific foundation. Every idle "shot" of state policy costs taxpayers dearly, and most importantly takes the country away from the general civilization flow.

In modern Russian reality, it seems that the moment has come when, after centuries of oblivion of human interests and the priority of state interests, welfare becomes not only a condition for stable socio-political development, but also an imperative for preserving and multiplying the people themselves.

According to a survey conducted in august 2019 by the Levada Center, 59\% of Russians expressed concern about rising prices and $42 \%$ about the impoverishment and poverty of the population [1].

\footnotetext{
* Corresponding author: aero789@mail.ru
} 
By a special decree, the President of Russia defined the country's development goals until 2030, which provide for "reducing the level of poverty by half compared to the indicator of 2017". [2]

One of the mechanisms for overcoming poverty and solving social problems of life support, which has proven its effectiveness in world practice, is consumer cooperation.

In fact, the Russian experience of developing consumer associations is so extensive and multifaceted that it allows us to identify both dead-end and constructive directions of the cooperative movement. [3]

Nevertheless, cooperative construction in modern Russia functions within the centralized structure of the Centrosoyuz inherited from the Soviet past and partially privatized. Obviously, the practices developed by Centrosoyuz over a seventy-year history, at least, do not stimulate the self-activity of the population and the regeneration of the natural qualities of consumer cooperation.

It is particularly annoying that domestic consumer cooperation, if not dying, is clearly not developing, while the international cooperative movement fully demonstrates a great constructive and constantly expanding potential in solving major social problems, including overcoming poverty.

This proves the relevance of the analysis of global cooperative practices to determine the guidelines and as a driver for the development of cooperation in general and domestic in particular.

A. Fici devoted his work to the reflection of cooperative identity in cooperative law. [4] There are review articles analysing the world experience of cooperation development. [5]

Considerable scientific literature is devoted to proving the effectiveness of a cooperative organization in overcoming poverty and providing comfortable living conditions for the population. [6], [7]

H. Munkner notes that industrial cooperation is irrelevant for low-income segments of the population. At the same time, continuing the logic of the researcher, it should be noted that the lack of socialized property of small producers in cooperation is not an obstacle to the cooperative organization of the poor in consumer societies. [8] In connection with the author's remark, it is reasonable to conclude that production and consumer cooperatives have different, in terms of their degree of constructiveness, potential in overcoming poverty. [9]

It is important to note (from the point of view of modern Russian experience) that the authors who specifically studied the conditions for the cooperative development in countries that have thrown off the colonial yoke, noted the fact that mandatory participation in centralized cooperative structures imposed on the population did not bring any tangible results. [10]

\section{Materials and Methods}

To analyse the international experience in the development of consumer cooperation, we used a phenomenological approach that allows us to define this institution as a unique social organization with its own special essential qualities.

The most complete reflection of the global positive potential of the consumer cooperative organization was made possible by using the comparative method, which allowed us to fully assess the general and special qualities of consumer associations.

The author draws empirical material from reviews of international cooperative organizations, in particular, the International Cooperative Alliance and regional cooperative structures. 


\section{Results. Consumer cooperation and poverty: an established alliance}

Since its inception, consumer associations have become an effective tool for social protection of the population least affluent part.

As the results of the analysis of data on the 300 largest cooperatives [11] show, these structures make efforts to achieve all the sustainable development goals in one way or another, and most of them pay special attention to ensuring the transition to rational consumption and production models (goal 12). They also take measures to combat climate change and its impacts (goal 13), ensure healthy lifestyles and promote well-being for all at all ages (goal 3), and promote sustained, inclusive and sustainable economic growth, full and productive employment and decent work for all (goal 8).

In contrast to production cooperation, which was one of the areas of concentration of small-scale commodity production, the genesis of which fell on the era of initial capital accumulation, consumer unions, a relatively young form of cooperative organization, its mass development is associated with the heyday of "free capitalism" and was initiated by the unification of collective efforts of workers in providing products and services for life.

By its nature, production cooperation is a form of organization of a commodity economy and cannot be anything other than a profit - oriented enterprise. Its social content (experts pay attention to the existence of such content) is connected, first, with the democratic principles of functioning (full harmonization of labor and property relations), and secondly, with the limited possibilities of using hired labor. The replacement of owner's co-operation with employee's co-operation inevitably leads to the elimination of the natural advantage of the co-operative form of organization: highly motivated work of owners, and, ultimately, to its deprivation, rebirth into an entrepreneurial structure. Lengthy arguments on this subject are appropriate, since in the world literature there is no clear differentiation of production partnerships and consumer associations.

As a result, for example, there is still a debate about the potential of cooperatives to overcome poverty, which is quite relevant in the case of assessing the capabilities of consumer societies and the absolute inadequacy of small producer's cooperatives to get rid of this social flaw. [12]

By definition, industrial cooperation cannot unite the poor, since its foundation is based on socialized small-scale property. On the contrary, consumer associations ultimately took place in connection with the social strategy of those who need to receive products and services with minimal costs.

\subsection{Consumer associations as a special type of cooperation}

Despite the fact that in the United States, in general, the cooperative's form organization is considered as one of the business models, nevertheless, in the academic environment, the discourse of defining consumer societies as a special type of cooperation is being updated.

The beginning of legal support for cooperation in the United States was laid by the Wisconsin Cooperation Act of 1887, which in the editions of 1911, 1921 and 1989 was distributed in 16 more States. The law regulates the formation, decision-making and functioning of governing bodies in cooperative enterprises. [13]

Under Wyoming law, cooperative enterprises can operate in the form of a limited liability company, a joint-stock company that issues securities to attract outside investors, or even as a corporation. Cooperatives are taxed "at the same rate as ordinary enterprises". Profits and voting rights in American cooperatives may be distributed not necessarily in accordance with the fundamental cooperative principle: "one participant - one vote", but, in 
particular, taking into account even the investment participation of members or even third parties. [13]

Bearing in mind the general assessment of cooperation as a type of business corporation the authors of an extensive work on American cooperative practice write: "In many ways, cooperatives are very similar to other types of corporations. They all participate in the same labor and capital markets and must pay similar salaries and interest rates and bear management costs. Many operational practices, such as packaging, storage, transportation, processing, and advertising, are also the same across all business models. Research has shown that cooperatives and other corporations are equally effective. And of course, general economic conditions - unemployment, interest rates, inflation, etc. - affect all corporations in the same way. A casual consumer usually can't tell who they are doing business with, a co-op or a corporation (unless, of course, the "co-op" is part of the named company).

The fundamental difference between cooperatives and other corporations is the focus on the needs of cooperatives, but not on investors. Cooperatives focus on getting the benefits (which may or may not be the profits) of members, while other corporations focus on the profits of their investors. Because of this, the operating philosophy between them can be very different. Cooperatives are often created to fill gaps in the market (for example, to provide vital services), and not just to generate corporate profits." [13]

Without going into a polemic about the American vision of cooperative identity, we note that the practice itself forces even supporters of radical liberal thought, who absolutize private capitalist forms of organization of the market economy, to recognize a "special type of cooperation" in consumer societies. [13]

Most representatives of cooperative thought in the United States recognize that the development of consumer cooperation became widespread during the Great Depression, when "people everywhere tried to save on household expenses." At that time, the most common form of consumer societies was "food cooperatives" that delivered products at optimally low prices.

Currently, US consumer unions are growing at a much faster rate than other types of cooperatives. Food associations of consumers still play a great role in supplying the population with food, only with the novelty that the goal of providing products at low prices has been added to the task of delivering natural and environmentally friendly products to consumers.

The structure of American consumer cooperatives is as follows. Companies for the supply of "green" products unite more than half a million shareholders and another 4,000 associations with 88,000 shareholders are focused on delivering products at minimum prices. [13]

Within the US consumer cooperative, the fastest growing segment is the consumer financial cooperative (credit and insurance) segment. Almost a third of the US population is united in 10,000 credit unions. Credit companies work successfully in the environment, pensioners, students and even school students. Membership in insurance cooperatives unites up to $25 \%$ of rural teachers. Consumer societies in the utility sector are becoming more widespread in the United States. Almost 1,000 cooperatives provide telephone service in rural areas, and 37 million villagers are members of construction and utility cooperatives. Cooperative health facilities provide medical services to more than 1 million Americans. The circle of consumer cooperation is constantly expanding, memorial cooperatives, associations of florists, hotels, recreation and tourism organizations, and energy companies are emerging (865 cooperatives with 37 million shareholders). [13]

In connection with the development of consumer cooperation, the task of its special legal regulation is being updated. Until now, the rules concerning the functioning of consumer associations are regulated by industry legislation (the Federal law on housing - 
1961, The law on rural electrification - 1949, etc.), which is a serious obstacle to their development. By the way, the unification of the law of the Russian Federation "On agricultural cooperation" (the current latest version of the June 1, 2020) two different types of cooperatives (production and consumer) and inadequate interpretation of the content of cooperative activities in the sphere of consumption is also a serious obstacle to the growth of the cooperative movement.

The American entrepreneurial model of cooperative construction, despite the rich European experience, has largely determined the special direction of the post-communist transformation of cooperation in the countries that are part of the "socialist bloc".

In general, cooperation in Europe is developing at a significant pace. Every fifth European is a member of at least one cooperative. The number of co-operators increases by approximately $20 \%$ over the five-year period.

In order to represent the growth of consumer cooperation in relation to the general indicators of the development of European cooperation, we present the following data, calculated on the basis of the published European cooperative statistics report. (Table 1.) [14]

Table 1. The share of consumer cooperatives in the cooperative socio-economic sector in Europe, 2015 [14]

\begin{tabular}{|c|c|c|c|c|}
\hline \multicolumn{2}{|c|}{} & cooperatives & $\begin{array}{c}\text { number of } \\
\text { shareholders }\end{array}$ & $\begin{array}{c}\text { annual } \\
\text { turnover in } \\
\text { euros }\end{array}$ \\
\hline $\begin{array}{c}\text { All consumer } \\
\text { cooperatives } \\
\text { and societie } \\
\text { of the EU }\end{array}$ & aбc & 176461 & 141502512 & 1,005 billions \\
\cline { 2 - 5 } & in \% of total quantity & $100 \%$ & $100 \%$ & $100 \%$ \\
\hline \multirow{2}{*}{ Housing } & aбc & 37500 & 11189933 & 21,18 billions \\
\cline { 2 - 5 } & in \% of total quantity & $21,20 \%$ & $7,80 \%$ & $0,20 \%$ \\
\hline \multirow{2}{*}{ Food } & aбc & 11546 & 37385400 & 102,6 billions \\
\cline { 2 - 5 } Energy & in \% of total quantity & $6,50 \%$ & $26,40 \%$ & $10,40 \%$ \\
\cline { 2 - 5 } & aбc & 1250 & 300000 & 979,5 millions. \\
\hline \multirow{2}{*}{ Healthcare } & aбc & $0,70 \%$ & $0,30 \%$ & $0,90 \%$ \\
\cline { 2 - 5 } & in \% of total quantity & $0,42 \%$ & $0,02 \%$ & $0,80 \%$ \\
\hline \multirow{2}{*}{$\begin{array}{c}\text { Credit and } \\
\text { insurance }\end{array}$} & aбc & 4200 & 60500000 & 7,39 billions \\
\cline { 2 - 5 } & in \% of total quantity & $2,40 \%$ & $42,80 \%$ & $0,73 \%$ \\
\hline \multirow{2}{*}{ Service } & aбc & 60000 & 2809850 & 85,0 billions \\
\cline { 2 - 5 } & in \% of total quantity & $34,10 \%$ & $1,98 \%$ & $8,40 \%$ \\
\hline \multirow{2}{*}{$\begin{array}{c}\text { All consumer } \\
\text { cooperatives }\end{array}$} & aбc & 115251 & 112188183 & 218,5 billions \\
\cline { 2 - 5 } & in \% of total quantity & $65,10 \%$ & $79,20 \%$ & $21,70 \%$ \\
\hline
\end{tabular}

Despite the fact that according to the table, consumer cooperation is the most dynamically developing type of cooperation (the exception is, for obvious reasons, the annual turnover of consumer societies of $21.7 \%$, since they are focused not on commercial activities, but on delivering benefits to shareholders), an adequate reflection of its identity in the national legislation of European countries is far from universal. For example, cooperation in the Czech Republic is regulated by Law 90/2012 on commercial companies and cooperatives, in Croatia, the law on cooperation was amended in 2014 regarding cooperative entrepreneurship, the Finnish cooperative Law allows for the establishment of a cooperative enterprise by a single founder, and in Belgium the activities of cooperatives as well as business structures are defined by the Law of June 20, 1991 on "Limited liability 
cooperatives" and the Law of May 7, 1999 on "Unlimited liability cooperatives". Austrian legislation is undifferentiated by type of cooperative activity.

Special laws for consumer associations and "social cooperation" operate in Italy, France, and Greece 4019 (2011). The Greek cooperative law provides for a minimum number of shareholders for consumer societies of 100 people.

Thus, despite the fact that consumer cooperative associations are the fastest growing type of global cooperative movement, the problem of defining their specific identity has not yet been solved.

\section{Discussion. Dissemination of international experience in the development of consumer cooperation as a factor of its growth}

In their research, A. Benzon and E. Brander, analyzing the experience of implementing a special project of the European platform for the development of cooperation (CEDP), showed that the exchange of best practices between the world's cooperative organizations is an important factor in the growth of the cooperative movement. [15]

The European cooperative development platform (CEDP) is a network of 10 European cooperative organizations that are members of Cooperatives Europe and work on cooperative development policy issues. As representatives of various sectors, participants share their experience in complementary areas: cooperative finance, agricultural cooperative development, cooperative law, etc.

In 2008, European cooperative structures supported the initiative to create such an institution. Since then, the organization has formed 74 branches in all countries of the world. Cooperatives of the countries united by the CEDP are included in a single information network, which is regularly updated. (Table 2.) [16]

Table 2. Consumer cooperative development projects implemented by CEDP [16]

\begin{tabular}{|l|l|l|}
\hline Project name & \multicolumn{1}{|c|}{ Country } & \multicolumn{1}{|c|}{ Project content } \\
\hline Coop Sur & $\begin{array}{l}\text { Paraguay, Bolivia, } \\
\text { Chile, Peru, Uruguay }\end{array}$ & $\begin{array}{l}\text { By encouraging cooperative self-help, the } \\
\text { project promotes broad-based economic and } \\
\text { social participation, improves local and } \\
\text { regional economic and social structures, and } \\
\text { thus reduces poverty in selected South } \\
\text { American countries. The project aims to } \\
\text { strengthen cooperative structures in } \\
\text { agriculture, the real economy and the } \\
\text { financial sector. (2019-2021) }\end{array}$ \\
$\begin{array}{l}\text { Project to mitigate the } \\
\text { effects internal } \\
\text { displacement }\end{array}$ & Colombia & $\begin{array}{l}\text { Project goal: preventing poverty among } \\
\text { displaced populations, through Cooperative } \\
\text { Financiera CFA which provides advice and } \\
\text { training to groups in accessing markets and } \\
\text { purchasing products at fair prices (2015-2021 } \\
\text { years.) }\end{array}$ \\
\hline $\begin{array}{l}\text { Regional project for the } \\
\text { development } \\
\text { cooperative self-Help } \\
\text { organizations in Asia }\end{array}$ & Vietnam, Philippines, \\
Thailand & $\begin{array}{l}\text { Strengthening cooperative structures in rural } \\
\text { areas in the field of services, credit, through } \\
\text { the participation of financially disadvantaged } \\
\text { groups of the population. (1999-2020) }\end{array}$ \\
& \\
\end{tabular}


Table 2. Continued

\begin{tabular}{|l|l|l|}
\hline $\begin{array}{l}\text { BRS Microfinance } \\
\text { Coop. }\end{array}$ & $\begin{array}{l}\text { Nicaragua, El } \\
\text { Salvador, Honduras, } \\
\text { Mexico, Senegal, } \\
\text { Cambodia, India, } \\
\text { Indonesia, }\end{array}$ & $\begin{array}{l}\text { Creation of a transcontinental financial } \\
\text { (lending, insurance) cooperative structure } \\
(2016 \text { to 2030) }\end{array}$ \\
\hline $\begin{array}{l}\text { Regional network rural } \\
\text { development }\end{array}$ & Macedonia & $\begin{array}{l}\text { Women's self-organization in improving } \\
\text { living conditions in rural communities (2018- } \\
\text { 2022) }\end{array}$ \\
\hline $\begin{array}{l}\text { Institutional support for } \\
\text { the NFFM }\end{array}$ & Moldova & $\begin{array}{l}\text { Creating conditions for broad access of the } \\
\text { rural population to social benefits: education, } \\
\text { health care, etc. (2018-2020) }\end{array}$ \\
\hline $\begin{array}{l}\text { The development of } \\
\text { housing and living } \\
\text { environment through } \\
\text { cooperatives }\end{array}$ & sri lanka & $\begin{array}{l}\text { Organization of housing and construction } \\
\text { cooperatives } \\
\text { (2018-2022) }\end{array}$ \\
\hline $\begin{array}{l}\text { Social development of } \\
\text { marginalized women } \\
\text { and girls }\end{array}$ & sri lanka & $\begin{array}{l}\text { Development of cooperative structures for } \\
\text { the socialization of marginalized women and } \\
\text { girls } \\
\text { (2018-2022) }\end{array}$ \\
\hline WiseGRD & $\begin{array}{l}\text { Italy, Belgium, Spain, } \\
\text { Greece } \\
\text { energy and renewable energy sources (2017- } \\
\text { 2020 years.) }\end{array}$ \\
\hline
\end{tabular}

The CEDP projects confirm the position that constructive international experience of cooperation, if there is a detailed information and organizational work, it can be replicated, can have a great creative potential. In addition, it is the organization of self-help, formalized in consumer associations that do not require large-scale investments and preliminary objective prerequisites, that is the most adequate from the point of view of the development of the world cooperative movement.

The scope of the article does not allow us to fully present even some of the most striking successes in the development of consumer cooperation.

\section{Conclusion}

To summarize the results of the research, it is necessary to use, in addition to the author's judgments, a reference to the presentation material of the European Cooperative Union. [17]

1. "The cooperative movement is a vital part of civil society."

2. Unlike industrial cooperation, consumer cooperation does not require pre-conditions for development in the form of an emerging small-scale way of life, it is stimulated by the dissemination of constructive international experience promoted by information and organizational activities.

3. Due to its essential qualities, the consumer cooperation segment of the world cooperative movement is the most dynamically developing.

4. "Supporting the launch and growth of cooperatives (through information and organizational work and promotion of international experience) is an established practice, a way to give people the opportunity to take responsibility for their own development."

5. The scope of "responsibility" of consumer cooperatives and their activities increases with the growth of consumer requests.

6. In the international movement promoting the principles of self-help, "there is a high degree of cooperation among cooperatives. Strong cooperative networks enable effective exchange of best practices and knowledge." 


\section{Acknowledgments}

The Work was carried out within the framework of the RFBR grant 18-010-00437 "Cooperation as an instrument for development rural areas and economic self-organization of population", contract № 18-010-00437\20 dated March 31, 2020.

\section{References}

1. A. Petrov, What worries Russians this year?, https://www.e.vesti.ru

2. Decree on national development goals of Russia until 2030, https://kremlin.ru/news/63728

3. N. K. Figurovskaya, Cooperation: pages of history, 3 (1998-2006)

4. A. Fici, Cooperative identity and the Law. Enricse Working Paper, 023112, 1 (2012)

5. N.A. Kwapong, M. Hanisch, Journal of Rural Cooperation, 41 (2), 114 (2013)

6. P. Develtere, I. Pollet, F. Wanyama, Cooperating out of poverty: The renaissance of the African cooperative movement. Dar es Salaam, ILO, World Bank Institute (2008)

7. F. Wanyama, P. Develtere, I. Pollet, Encountering the Evidence: Cooperatives and Poverty Reduction in Africa. Catholic University of Leuven, Belgium, and other. (2008)

8. H. Münkner, Co-operation as a Remedy in Times of Crisis. Agricultural Co-operatives in the World: Their Role for Rural Development and Poverty Reduction. Marburg Studies on Cooperation and Cooperation, 58 (2012)

9. R. Simmons and J. Birchall, Journal of Socio-Economics, 37, 2131 (2008)

10. S. Vicari, Understanding Co-operatives' Potential in Fighting Global Poverty in a Human Development Perspective". Paper presented at the ICA Research Conference on "The Role of Co-operatives in Sustaining Development and Fostering Social Responsibility", Riva del Garda, October 15-18, (2008)

11. Report of the UN Secretary-General, Social development: social development, including issues related to the world social situation and youth, older persons, disabled persons and the family, Cooperatives in social development, (2019)

12. N.A. Kwapong, M. Hanisch, Cooperatives and Poverty Reduction: A Literatuse Review Journal of Rural Cooperation, 41 (2), 114 (2013)

13. K.A Zeuli, R. Cropp, Cooperatives: Principles and practices in the $21^{\text {st }}$ century, https://www.academia.edn/

14. Cooperatives Europe. The Power of cooperation. Cooperatives Europe Key figures (2015), https://coopseurope.coop/

15. A. Benzon, E. Brauder, Good practices in international cooperative development: Why creating a knowledge sharing culture is key for international cooperative development work, https://coopseurope.coop/

16. The CEDP Website and compendiumaim to foster exchanges and collaboration for an impact-driven cooperative development approach, and can be found, https://coopseurope.coop/development/

17. Sharing the benefits, International development through cooperatives, https://coopseurope.coop/ 